The Mexican Wars for Independence. By Timothy J. Henderson. New York: Hill and Wang, 2009. Pp. xxiii, 222. Illustrations. Maps. Notes. Bibliography. Index. $\$ 27.50$ cloth.

While there are at least a half dozen comprehensive books on the Mexican Revolution aimed at a general audience, there is not much to choose from for the independence period. Timothy Henderson's text seeks to fill this niche, just in time for Mexico's bicentennial. This book gives an overview of some of the causes and events of independence, focusing especially on the leaders Miguel Hidalgo, José María Morelos and Agustín de Iturbide. It is sharply written, divided into brief chapters without many of those bothersome footnotes that the general public finds annoying. However the barebones approach does not do justice to this intensely difficult period and Henderson reduces complex issues to simple declarative sentences. He affirms in the prologue, "This was no melting pot, but a rigid caste system" (p. xx), and he assigns much explanatory power to simplified motives of racial or economic resentment. On the other hand, the book has plenty of blood and gore to keep students from complaining in their course evaluations that the readings are boring.

While some of the newer research on the era informs the text, it has an antiquated feel generally. The chapters on the insurrection and the war that followed could have been written 40 years ago. While there is some effort to restore the importance of constitutional debates in both the royalist and insurgent camps, his discussion of the Constitution of Apatzingán is dismissive. Futher, though the author justifiably seeks to redress the black legend surrounding Iturbide (following the work of Timothy Anna), Henderson generally has a very sour view of the revolution and focuses on the personality disorders of the leadership and missed military opportunities. I suspect this is due to the specter of nineteenthcentury conservative stalwart Lucas Alamán, which haunts the book; he is the source the author relies on whenever a gory tale needs to be told, and Alamán excelled at such stories since he wrote about the war as a lesson in the awful impact of the masses on politics.

Noting that even as late as 1924 , then President Plutarco Calles excluded Iturbide from the pantheon of heroes, Henderson is aware that the history of the wars of independence was contentious. The major nineteenth-century intellectuals of every political faction dedicated their time and energy to produce a fascinating historiography of the upheavals, as Independence became the prism through which Mexicans wrestled with creating a nation. Lucas Alamán was more than a conservative writing the history of the independence movement; he was writing the war to make a conservative Mexico, just as Lorenzo de Zavala wrote his to create a popular federal Mexico. Writing about the wars of independence without Alamán, Zavala or Carlos María de Bustamante is impossible, but using them is also fraught with pitfalls.

Further, many of the citations of primary sources are drawn from secondary sources, creating opportunities to lose the sense of the original. For example, the phrases cited from Bustamante's description of Iturbide are taken so out of context as to miss the author's viciously negative opinion of Iturbide and overlooks the staunch republican's mocking tone towards the Emperor's cult of personality. Bustamante was willing to concede that 
his nemesis was a tireless military campaigner but only after describing him as immoral and duplicitous to the core.

The author fails to draw comparisons with other continental independence movements, a regrettable choice given his broad audience. The Mexican conflict would seem less confusing, bloody, and generally freaky if he reminded readers that the wars for independence in North and South America were also terrible. It would have been more useful to end with some meditations on how contemporaries made revolutions and how the state managed to reconstruct itself afterwards. Finally, instead of treating Independence as the prologue to Mexico's difficult nineteenth century, Hendeson launches into a discussion of the revolution of 1910 , as if nothing of much importance happened between 1824 and 1910. Decolonization does not end when the shooting stops, and the fallout from independence deserves more than the brief final paragraphs provided here.

\section{Universidad Veracruzana}

Michael T. DuceY

Xalapa, Veracruz, Mexico

Historias de la cartografía de Iberoamérica: nuevos caminos, viejos problemas. Edited by Héctor Mendoza Vargas and Carla Lois. Mexico City: Instituto de Geografía de UNAM, 2009. Pp. 494. Maps. Tables. Bibliography. Photographs.

In recent decades, scholars from diverse disciplines have taken up the study of maps and mapping as a field of interest. Their research on the history of cartography deploys crossdisciplinary perspectives and methodologies that interrogate maps as scientific, cultural, and visual productions. The result has been conferences, seminars, and numerous scholarly publications, including the epic multivolume History of Cartography (1996- ). This burgeoning international scholarship provides the context for this collection of essays in which researchers from a variety of disciplines, countries, and continents write on the history of Iberoamerican cartography.

In their introduction, "Viejos temas, nuevas preguntas: la agenda de la historia de la cartografia iberamericana hoy," Héctor Mendoza Vargas and Carla Lois trace the broadening of the study of maps to embrace cultural as well as scientific perspectives, citing the foundational and highly influential work of J.B. Harley. As a result, they suggest, scholars of Iberoamerican cartography are investigating new roads not only manifested by an increased interest in the conservation of maps but also in the growth of interpretive studies.

The breadth and depth of this ongoing research is evident in this collection of 19 original and revised essays (selected from conferences held in Buenos Aires and Mexico City), which are organized into four sections. In "Las representaciones cartográficas," the authors analyze mapping associated with cities and towns from the sixteenth to nineteenth centuries. Their articles identify the exchange of cartographic ideas between Chinese and Portuguese maps of Macao; trace the colonial cartography of Buenos Aires from notarial (written) descriptions to graphic images; and deconstruct the 1580 map of the Mexican town of Huaxtepec, reconstructing the presence of Spanish as well as Mesoamerican references. 